\title{
Позднерифейские морозовские субвулканические базальтоиды северо-западного Пай-Хоя
}

Вовчина Т.A.

Институт геологии ФИЦ Коми НЦУрО РАН, Сыктывкар, ta_kaneva@mail.ru

Аннотация. Приводятся результаты петрологического и минералогического исследований базальтов и андезибазальтов, входящих в состав морозовских субвулканических образований северо-западного ПайХоя (Амдерминский район). Определенным критерием отличия субвулканических образований от эффузивных пород является обильное количество в них крупных порфировых короткопризматических вкрапленников клинопироксена (ряда эндиопсид-диопсид-авгит) размером до 1.5 см. Установлено, что клинопироксены имеют зональность, связанную с фракционной кристаллизацией магмы (обогащение краев зерен $\mathrm{Fe}, \mathrm{Al}$ ). Pacчеты средних показателей железистости клинопироксенов показали, что субвулканические базальтоиды кристаллизовались при более высокой температуре на большей (но незначительно) глубине по сравнению с эффузивными породами морозовской свиты.

Ключевые слова: базальт, андезибазальт, клинопироксен, субвулканические образования, морозовская свита, поздний рифей, Пай-Хой.

\section{Late Riphean Morozov subvolcanic basaltoids of the northwestern Pay-Khoy}

\section{Vovchina T.A.}

Institute of Geology, Federal Research Centre of the Komi Science Centre, Ural Branch, RAS, Syktyvkar, ta_kaneva@mail.ru

Abstract. The results of petrological and mineralogical studies of basalts and andesibasalts that are part of the Morozov subvolcanic bodies of the northwestern Pay-Khoy (Amderma region) are reported. A certain criterion for distinguishing subvolcanic bodies from effusive rocks is the plentiful number of large porphyry short-prismatic inclusions of clinopyroxene (a series of endiopsid-diopsid-augite) up to $1.5 \mathrm{~cm}$ in size. It was established that clinopyroxenes have a zoning associated with fractional crystallization of magma (enrichment of the edges of $\mathrm{Fe}, \mathrm{Al}$ grains). Calculations of the average iron content of clinopyroxene showed that subvolcanic basaltoids crystallized at a higher temperature at a greater (but insignificant) depth compared to effusive rocks of the Morozov Formation.

Keywords: basalt, andesibasalt, clinopyroxene, subvolcanic bodies, Morozov Formation, Late Riphean Pay-Khoy.

\section{Введение}

В пределах вулканогенно-осадочной верхнерифейской морозовской свиты северозападного Пай-Хоя присутствуют многочисленные субвулканические тела, которые являются наиболее ярким свидетельством положения очага активного вулканизма. Именно к субвулканическим, а не эффузивным эти образования впервые были отнесены А.С. Микляевым в 1971 г. на основании общегеологических наблюдений.

С помощью результатов петрологических и минералогических исследований нами предпринята попытка определения принадлежности этих образований к субвулканическим в составе морозовской свиты северо-западного Пай-Хоя.

\section{Геологическое строение района}

В геологическом строении северо-западной части Пай-Хоя значительную роль играют островодужные образования позднерифейско-вендского возраста, которые находятся в ядре антиклинальной структуры Амдерминского блока. Амдерминский блок представляет собой горст-антиклинорий (рис. 1), северо-восточное крыло которого сложено карбонатными отложениями амдерминской свиты $\left(\mathrm{RF}_{3}-\mathrm{V} a m\right)$, а юго-западное - вулканогенно-осадочными и терригенными породами морозовской 


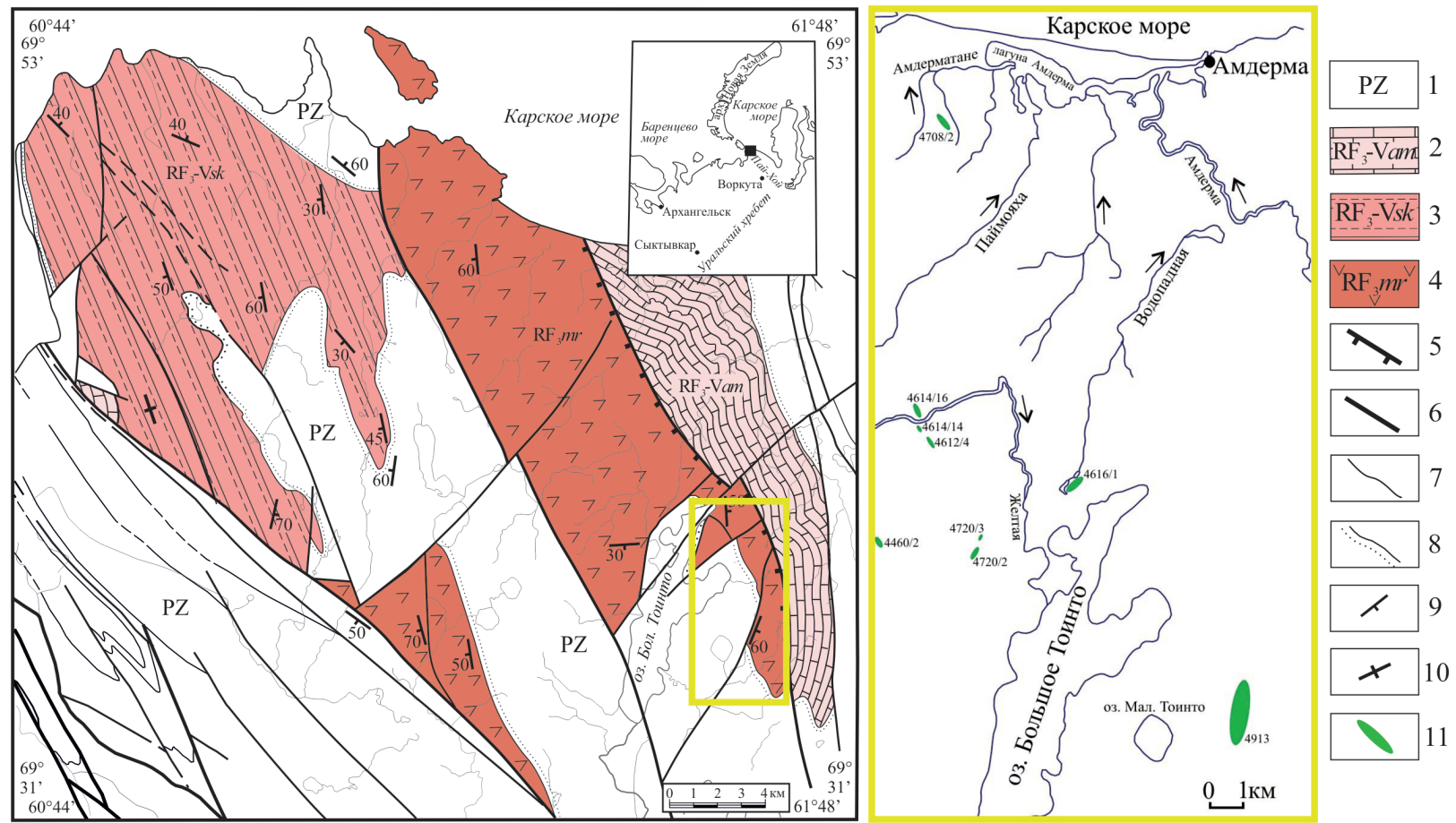

Рис. 1. Схема геологического строения Амдерминского блока, северо-западный Пай-Хой. Составлена по материалам ГДП-200 ЗАО «Поляргео», 2015 г., с изменениями.

1 - палеозойские отложения; 2 - амдерминская свита $\left(\mathrm{RF}_{3}-\mathrm{V} a m\right)$ : кристаллические, микрофитолитовые известняки, редкие линзы кремней, тонкокристаллические углеродистые известняки; 3 - сокольнинская свита $\left(\mathrm{RF}_{3}-\mathrm{V} s k\right)$ : песчаники, алевролиты, гравелиты, кремнистые сланцы, туфопесчаники, базальты, андезиты, риодациты, риолиты и их туфы, субвулканические образования; 4 - морозовская свита $\left(\mathrm{RF}_{3} m r\right)$ : сланцы глинистые, кремнистые и углеродистые, известняки, доломиты, сланцы по кислым туфам, базальты, андезибазальты, андезиты, риодациты, их туфы, туфопесчаники, субвулканические образования; 5 - надвиги; 6 - разрывные нарушения; 7-8 - границы стратиграфических подразделений: 7 - согласные, 8 - несогласные; 9-10 - структурные элементы: 9 - наклонное залегание, 10 - вертикальное залегание; 11 - субвулканические тела морозовской свиты.

Fig. 1. Schematic geological structure of the Amderma block, northwestern Pay-Khoy, compiled on the basis of materials of additional geological study, scale 1:200 000, Polyargeo Company, 2015, modified.

1 - Paleozoic sediments; 2 - Amderminskaya Formation $\left(\mathrm{RF}_{3}-\mathrm{Vam}\right)$ : crystalline, microphytolithic limestones, rare chert lenses, fine-grained crystalline carbonaceous limestones; 3 - Sokolninskaya Formation $\left(\mathrm{RF}_{3}-\mathrm{V} s k\right)$ : sandstones, siltstones, gravelites, chert shales, tuffaceous sandstones, basalts, andesites, rhyodacites, rhyolites and their tuffs, subvolcanic rocks; 4 - Morozov Formation $\left(\mathrm{RF}_{3} m r\right)$ : shales, cherts and carbonaceous shales, limestones, dolomites, schistose felsic tuffs, basalts, andesites, andesibasalts, rhyodacites, their tuffs, tuffaceous sandstones, subvolcanic rocks; 5 - thrusts; 6 - faults; 7-8 - geological boundaries: 7 - between units with conformable bedding, 8 - unconformity; 9-10 - structural units: 9 - inclined bedding, 10 - vertical bedding; 11 - subvolcanic bodies of the Morozov Formation.

$\left(\mathrm{RF}_{3} m r\right)$ и сокольнинской $\left(\mathrm{RF}_{3}-\mathrm{V} s k\right)$ свит. Внутреннее строение докембрийского комплекса, выходящего на поверхность в пределах этого блока, осложнено крупным субмеридиональным надвигом, проходящим в его восточной части. По надвигу отложения, распространенные в осевой и югозападной частях Амдерминского блока, надвинуты на породы, слагающие его северо-восточную часть. Стратиграфических переходов между породами картируемых подразделений не выявлено, все три свиты имеют между собой тектонические контакты.

Небольшие позднепротерозойские интрузивные тела локализованы в полях распространения морозовской и сокольнинской свит. Среди них выделяются морозовские субвулканические образования основного состава и сокольнинские субвулканические образования кислого состава. 


\section{Объект исследования}

Объектом исследования являются обильнопорфировые базальты и андезибазальты, слагающие овально-вытянутые и линзообразные субвулканические тела в пределах морозовской свиты и наиболее распространенные восточнее оз. Малое Тоинто, по рр. Желтая и Амдерматане (рис. 1). Протяженность тел различная - от 100 до 1500 м. В современном рельефе эти тела обычно образуют изолированные сопки или вытянутые гряды, возвышающиеся на 3-30 м над окружающим рельефом. Контакты с вмещающими породами субсогласные.

Определенным критерием отличия субвулканических тел от эффузивных пород является обильное количество в них крупных порфировых короткопризматических вкрапленников клинопироксена (ряда эндиопсид-диопсид-авгит) размером до 1.5 см.

Возраст субвулканических образований условно принимается позднерифейским на основании их локализации в полях распространения морозовской свиты.

\section{Аналитические методы}

Петрографический состав субвулканических базальтоидов изучался в прозрачных шлифах. Содержания петрогенных элементов определялись методом классического химического анализа в ЦКП «Геонаука» ИГ Коми НЦ УрО РАН (г. Сыктывкар) в соответствии с процедурами, описанными в (Унифицированные ..., 1979). Микрозондовый анализ проводился на спектральном электронном микроскопе Tescan Vega 3 LMH с эдс X-MAX 50mm Oxford Instruments в ЦКП «Геонаука» ИГ Коми НЦ УрО РАН (г. Сыктывкар). Содержания микроэлементов определены с использованием масс-спектрометрии с индуктивно-связанной плазмой (ICP-MS) во ВСЕГЕИ (г. Санкт-Петербург) по методике, опубликованной на сайте https:/vsegei.ru/ru/activity/labanalytics/lab/lab-operations/ masspec.php.

\section{Петрографическая характеристика}

На макроуровне изученные породы серовато-зеленого цвета, с многочисленными порфировыми вкрапленниками плагиоклаза и пироксена. Микроскопически породы характеризуются обильнопорфировой и сериально-порфировой структурой и миндалекаменной или массивной текстурой.

Порфировые вкрапленники сложены соссюритизированными табличками и лейстами плагиоклаза (0.4-1.4 мм), их гломеропорфировыми сростками, призматическими зернами клинопироксена ряда эндиопсид - диопсид - авгит (до 60 \% общего объема вкрапленников, 4-17 мм), в центре нередко замещенными волокнистым хлоритом (пикнохлоритом и рипидолитом), актинолитом, эпидотом, клиноцоизитом. В основной массе лепидонематогранобластовой структуры присутствуют мелкие лейсты альбита, чешуйки хлорита (пикнохлорита и диабантита) и серицита, иголочки актинолита и магнезиальной роговой обманки, скопления мелких зерен эпидота и клиноцоизита, мелкие ксеноморфные угловатые зерна титанита, апатит.

\section{Петро- и геохимические характеристики}

По петрохимической классификации субвулканические морозовские образования принадлежат к семействам базальтов и андезибазальтов нормального и субщелочного петрохимического ряда. Содержание $\mathrm{SiO}_{2}$ в них варьирует в пределах 41.27-55.77 мас. \% при сумме щелочей 2.04-6.53 мас. \%. Они представляют собой натриевые и калиево-натриевые породы. Исходя из содержания $\mathrm{K}_{2} \mathrm{O}$ подавляющая часть субвулканических образований характеризуются как низко- и к умереннокалиевые. По содержанию $\mathrm{Al}_{2} \mathrm{O}_{3}$ (6.6-18.29 мас. \%) являются высокоглиноземистыми (редко низкоглиноземистыми), а по содержанию $\mathrm{TiO}_{2}$ (0.31-0.88 мас. \%) - весьма и умереннонизкотитанистыми породами. Все субвулканические образования относятся к породам известково-щелочной серии. По химическому составу субвулканические базальтоиды соответствуют эффузивным породам основного состава морозовской свиты, что может свидетельствовать об их комагматичности (Канева, 2016).

В породах отмечается низкое содержание редких земель (сумма РЗЭ - 18.6-29.2 г/т).На диаграмме распределения РЗЭ выделяется горизонтальный тип графика, с очень слабым отрицатель- 
ным наклоном. Их составы незначительно больше обогащены легкими редкими землями относительно тяжелых $\left(\mathrm{La}_{\mathrm{N}} / \mathrm{Yb}_{\mathrm{N}}=1.5\right)$, дефицит европия не проявлен $\left(\mathrm{Eu}_{\mathrm{N}} / \mathrm{Eu}_{\mathrm{N}}{ }^{*}=0.6\right)$. Для распределения литофильных элементов-примесей характерны относительно повышенные содержания крупноионных элементов (K, Rb, Ba, Sr, Th) и низкие, ниже NMORB, содержания высокозарядных. Проявлен небольшой $\mathrm{Nb}$ минимум. Обедненность литофильными элементами-примесями, низкие содержания $\mathrm{Ti}$ и $\mathrm{Nb}$-отрицательная аномалия свидетельствуют о том, что магматический расплав формировался из мантии, истощенной в зоне субдукции.

На всех диаграммах (Мияширо, Вуда, Э. Муллена), используемых для реконструкции геодинамических обстановок формирования базальтоидов, точки составов рассматриваемых пород попадают в области островодужных образований.

\section{Минералогическая характеристика}

Минералы эффузивных и субвулканических пород морозовской свиты затронуты метаморфическими процессами (замещены новообразованными фазами и их смесями) и единственным породообразующим минералом, наиболее хорошо сохранившимся, является клинопироксен. С помощью метода микрозондового анализа нам удалось выявить зональность клинопироксенов, связанную с фракционной кристаллизацией магмы (обогащение краев зерен $\mathrm{Fe}, \mathrm{Al}$ ) (Сазонова, 1999).

В эффузивных базальтах морозовской свиты фенокристаллы сложены клинопироксеном и плагиоклазом. Основная масса представляет собой мелкозернистый агрегат хлорита (пикнохлорит, диабантит), амфибола (актинолит, винчит), эпидот-клиноцоизита и кальцита. Из акцессорных минералов были определены титанит и циркон.

Все клинопироксены относятся к подсемейству кальциевых пироксенов. Во вкрапленниках он диагностируется как эндиопсид, диопсид и авгит, в основной массе - авгит. Внутри зерен клинопироксенов, большая часть которых имеет сложную зональность, меняется показатель железистости $\left(f=\mathrm{Fe}^{2+} /\left(\mathrm{Fe}^{2+}+\mathrm{Mg}^{2+}\right) * 100\right)$ : от центров к промежуточным участкам зерен железистость уменьшается, а к краям наблюдается ее резкое увеличение. Но в основном наблюдается тенденция увеличения железистости от центра к краю. Также от центра к краю увеличивается содержание $\mathrm{Al}_{2} \mathrm{O}_{3}$ (1.9-2.47 в центре; 2.04-3.88 в краевых частях). Составы клинопироксенов свидетельствуют об отличающихся условиях кристаллизации: вкрапленники формировались на глубине и поэтому имеют невысокий показатель железистости $(f=10-26)$. Клинопироксен в основной массе обладает более высоким показателем железистости $(f=21-39)$ и, вероятно, формировался при более низких температурах по сравнению с температурой кристаллизации фенокристаллов.

В субвулканических базальтах и андезибазальтах морозовской свиты фенокристаллы сложены клинопироксеном и плагиоклазом. Основная масса представляет собой мелкозернистый агрегат хлорита (пикнохлорит), амфибола (актинолит, канниллоит), эпидот-клиноцоизита, мусковита, альбита. Из акцессорных минералов были определены титанит и хромшпинелид.

Во вкрапленниках клинопироксен определяется как эндиопсид, диопсид и авгит, в основной массе - авгит и субкальциевый авгит. Клинопироксены субвулканических образований обладают сложной зональностью. Исходя из наших наблюдений, мы можем выделить тренд, выражающийся в увеличении содержания $\mathrm{FeO}, \mathrm{Al}_{2} \mathrm{O}_{3}$ и в уменьшении содержания $\mathrm{MgO}, \mathrm{CaO}, \mathrm{SiO}_{2}$ по направлению к краям зерен. Этот тренд отражает нормальный ход дифференциации расплава, а также быстрое падение температуры кристаллизации клинопироксенов. Вероятно, кристаллизация каймы клинопироксена происходила в близповерхностных условиях.

Содержание $\mathrm{Al}_{2} \mathrm{O}_{3}$ в центральных частях составляет 1.46-2.41, а в краевых - 2.24-3.91. Наблюдается увеличение железистости от центра $(f=10-18)$ к краю $(f=13-23)$. Наиболее высоким показателем железистости $(f=25-30)$ обладает клинопироксен в основной массе, что указывает на различные температурные режимы и условия их формирования.

После расчета средних показателей железистости клинопироксенов видно, что у эффузивных вулканитов он немного выше $(f=14-20)$, чем у субвулканических образований $(f=13-19)$. Это мо- 
жет указывать на то, что субвулканические базальтоиды кристаллизовались при более высокой температуре на большей (но незначительно) глубине по сравнению с эффузивными породами морозовской свиты.

\section{Выводы}

Петрологические и минералогические исследования позволили установить принадлежность обильнопорфировых базальтов к субвулканическим морозовским образованиям. По химическому составу субвулканические базальтоиды соответствуют эффузивным породам основного состава морозовской свиты, что может свидетельствовать об их комагматичности.

Во вкрапленниках клинопироксена в эффузивных и субвулканических базальтоидах морозовской свиты от центра к краям зерен отмечается уменьшение содержаний $\mathrm{SiO}_{2}, \mathrm{MgO}$ и $\mathrm{CaO}$ и увеличение содержаний $\mathrm{Al}_{2} \mathrm{O}_{3}, \mathrm{FeO}$. Вкрапленники клинопироксенов характеризуются прямой зональностью. Железистость клинопироксенов из основной массы наиболее высокая. Такой тренд изменения составов соответствует нормальному ходу дифференциации расплава в процессе фракционной кристаллизации при достаточно высоком водном давлении (DeBari Susan, 1989), а также низкой для расплава активности кремнезема, которая способствует встраиванию алюминия в решетку клинопироксена (Chambers, 1995). Повышенная железистость кайм вкрапленников и клинопироксенов из основной массы может указывать на быстрое падение температуры в ходе кристаллизации расплава, что может иметь место, когда после быстрого подъема магмы формирование кайм фенокристаллов и мелких кристаллов основной массы происходило уже в близповерхностных условиях.

В целом для клинопироксенов из эффузивных базальтоидов морозовской свиты характерны повышенные концентрации $\mathrm{FeO}$ и пониженные содержания $\mathrm{CaO}$ по сравнению с клинопироксенами из субвулканических пород, что связано с более низкой температурой кристаллизации покровных вулканитов морозовской свиты. Клинопироксен из основной массы эффузивных пород морозовской свиты немного более железистый (f - 21-39), по сравнению с клинопироксеном из основной массы в соответствующих субвулканических базальтоидах (f - 25-30), что отражает более низкотемпературные условия кристаллизации пород покровной фации.

Работа выполнена в рамках темы НИР «Литосфера северо-востока Европейской платформы и севера Урала: вещественно-структурная эволюция, корреляция геологических событий, геодинамика, геохронология». ГР № АAАА-А17-117121270035-0.

\section{Литература}

1. Канева Т.А. Петрогенезис и геодинамика позднедокембрийских вулканитов северо-западного Пай-Хоя // Вестник И-та геологи Коми НЦ УрО РАН. Сыктывкар: Геопринт. 2016. № 12. С. 3-15. DOI: 10.19110/2221-1381-2016-12-3-15.

2. Сазонова Л.В., Носова А.А. Зональность клинопироксенов как функция условий остывания магматического расплава (на примере одинитов Урала) // Геохимия. 1999. № 12. С. 1268-1285.

3. Унифицированные методы анализа силикатных горных пород с применением комплексонометрии. Москва: Всесоюзный научно-исследовательский институт минерального сырья. 1979. 33 с.

4. Chambers A.D., Brown P.E. The Lilloise intrusion, East Greenland: fractionation of a hydrous alkali picritic magma // Journal of petrology. 1995. V. 36. No. 4. P. 933-962.

5. DeBari Susan M., Coleman R.G. Examination of the deep levels of an island arc: evidence from the Tonsina ultramafic-mafic assemblage, Tonsina, Alaska // Gournal of geophysical research. 1989. V. 94. No. B4. P. 4373-4391. 